\title{
Stage IV Gastric Cancer AJCC v6
}

National Cancer Institute

\section{Source}

National Cancer Institute. Stage IV Gastric Cancer A/CC v6. NCI Thesaurus. Code C9036.

Stage IV includes: (T4, N1-3, M0); (T1-3, N3, M0); (Any T, Any N, M1). M1:Distant

metastasis. (AJCC 6th ed.) - 2003 